\title{
Reviving Zimbabwe's Agriculture: The Role of China and Brazil
}

\author{
Langton Mukwereza
}

\begin{abstract}
From 2000, after Zimbabwe embarked on a major land reform programme, the country was isolated economically and diplomatically by Western countries. Agricultural financing dried up, and traditional Western donors only provided humanitarian assistance to communal farmers and refused to support any programmes in newly resettled areas. The government approached China and Brazil among other countries to help resuscitate the agricultural sector; including the newly resettled areas. While Brazilian assistance is yet to make a significant impact, as delivery modalities are still being worked out, Chinese assistance has made a significant impact particularly in the tobacco and cotton sectors. Only time will tell whether these new partnerships, as an alternative to Western aid, will become a success story of South-South cooperation.
\end{abstract}

\section{Introduction}

For much of the period since 2000, when Zimbabwe embarked on a major land reform programme, the country has been isolated economically and diplomatically from Western countries. Following the land reform, there was a withdrawal of aid by Western donors and development banks, credit lines disappeared and investment flows shrank dramatically. The Zimbabwe government had to look elsewhere for support, and a 'Look East' policy was announced. China offered significant loans as well as other forms of investment and aid, while Brazil promised support too. In its isolation from the mainstream development community, Zimbabwe's aid and investment relations were reshaped. This has been the case in the agricultural sector, as in other areas.

The agricultural sector is pivotal to the economy of Zimbabwe, providing 14-18 per cent of the Gross Domestic Product (GDP), 40 per cent of export earnings and 60 per cent of raw materials for industry (AMID 2012a). But following land reform, challenges of agricultural financing, land tenure security and technical support have been major challenges, and overall production in a number of key crops has declined. Prior to the abandonment of the Zimbabwe dollar currency and the creation of a multicurrency environment in 2009, rampant hyperinflation undermined the economy. Alternative sources of finance were essential, and the Reserve Bank of Zimbabwe attempted a variety of programmes, supported largely by loans from the Chinese. Meanwhile, the Western donors only engaged on the basis of humanitarian aid, refusing to support agricultural development in the new resettlement areas.

Thereafter, formally recorded outputs from the agricultural sector declined annually by $7.1 \mathrm{per}$ cent between 2000 and 2008, a cumulative decline of 79.4 per cent over the period between 2002 and 2008 (Ministry of Finance 2009).

Agricultural exports and total exports declined by 53 per cent and 27 per cent between 1999 and 2008 respectively (AMID 2012a). However, a stabilisation of the macro economy was achieved in 2009 with the formation of a Government of National Unity, and in some areas - notably tobacco and cotton - agricultural output has been booming.

Since 2009, the agricultural sector and the wider economy have been recovering, growing by 21 per cent in 2009, 33.9 per cent in 2010 and 7.4 per cent in 2011 (European Union 2012; Ministry of Finance 2011). The 2012 growth rate is expected to be 11.6 per cent (Ministry of Finance 2012). Central to this growth, will be the revitalisation of agriculture on the newly resettled lands. Under the Fast Track Land Reform Programme 
(FTLRP), 90 per cent of former large-scale commercial farmland (14.156 million out of 15.5 million hectares) was acquired and distributed among 232,738 households (Scoones et al. 2010; Pazvakavambwa 2007).

It is against this background that the government of Zimbabwe approached China and Brazil among other countries to explore opportunities for aid and cooperation programmes to support the country's agricultural sector, including in the newly resettled areas.

\section{Political alliances}

Zimbabwe African National Union - Patriotic Front (ZANU-PF) was the governing party in Zimbabwe from independence in 1980 up until the inauguration of the Government of National Unity in 2009. During that period, alliances and positions maintained by the ruling party and government were synonymous. After being ostracised by the West and international funding agencies following the land reform programme, China was sympathetic to the plight of Zimbabwe since strong links at party-to-party level had been established in the 1970s at the height of Zimbabwe's liberation struggle. China has been a natural ally which, along with Russia, vetoed all United Nations Security Council resolutions on sanctioning Zimbabwe. The cooperative relationship with Brazil, however, is more recent, and driven largely by commercial considerations and a determination to assert itself as a global economic power.

Ties between Zimbabwe and China were strengthened further in 2003 at the height of trade and targeted sanctions by developed countries with the country proclaiming the Look East policy. The policy aimed to expand trade and bilateral relations as well as promoting investments with China, Malaysia, Indonesia, Singapore, Japan, South Korea, Vietnam, India and Russia (Machadu 2012). The relationship has focused almost entirely on China, however. This is largely due to links between the Chinese Communist Party and ZANU-PF that date back to Zimbabwe's independence struggle, as well as China's espoused policy of non-interference in the internal affairs of sovereign countries.

Notable high-profile visits between Harare and Beijing and numerous Memoranda of Understandings (MoUs) have been signed.
Programmes with China include those between the two governments to those between non-state entities. Government-to-government programmes have been on building the capacities of specified units of the Ministry of Agriculture and its departments with the government of Zimbabwe not paying for the assistance. Cooperation between the private sectors of the two countries is largely through contract farming arrangements where the Chinese companies provide key inputs that the beneficiaries repay at the time of marketing the produce. Over the years, there has been an expansion of contract farming schemes for tobacco and cotton financed by Chinese firms; particularly with tobacco.

Agricultural cooperation with Brazil is still nascent, although now formalised with the signing of an MoU towards the end of 2011 on agricultural mechanisation and irrigation development under the More Food Africa programme. With work still under way in developing administrative procedures in both countries, the equipment has not yet been supplied. The programme blends a governmentto-government technical cooperation arrangement focusing on capacity building with a commercial component for procuring farm equipment on loan, subsequent maintenance, and the repayment of loans. As part of this new cooperation framework, a Zimbabwean private sector concern has already built a giant ethanol plant using Brazilian expertise.

All commercial arrangements between Zimbabwean farmers and the private sectors of the two countries are facilitated by the ministries of Agriculture of the two countries which additionally undertake an oversight role at both ends. Yet while day-to-day engagements are managed by the line ministry, higher level political interactions govern the relationship, especially for China. The solidarity shown in the face of Western sanctions has been an important facet of political relations in recent years, with China having increasing influence in various sectors, ranging from mining to the security sector.

\section{China's engagements in Zimbabwean agriculture}

Key cooperation programmes completed, under way and planned between Zimbabwe and China include the following list of engagements outlined in more detail later in this section: an 
Agricultural Technology Demonstration Centre (ATDC), Emergency Food Aid, a loan agreement with the Export-Import Bank of China, a donation of agricultural machinery by a provincial Chinese government, and the training of key staff in the government of Zimbabwe's Ministry of Agriculture.

The US $\$ 30$ million ATDC funded by China was commissioned at Gwebi Agricultural College, about $40 \mathrm{~km}$ north-west of Harare. The centre is in a prime farming area and presents an ideal setting for experimentation and running demonstrations. The three key objectives of the ATDC are:

- The provision of a setting for showcasing successes of technologies and methods of production from China;

- An all-round training centre for agricultural personnel, students and farmers;

- Provision of a centre for agricultural research and technology development including research in biotechnology.

The centre is a donation from the Chinese government and was established as part of the commitments made by China to Africa from the 2006 Forum on China-Africa Cooperation (FOCAC) conference and reiterated at subsequent such gatherings. The centre was commissioned in the first quarter of $2012^{1}$ and the Chinese company, Minoble, will run it for the next three years, thereafter handing it over to the host government. The centre will be absorbed as one of the Ministry of Agriculture's centres of excellence in research and extension that include research stations, farmer training centres, and agricultural colleges.

In February 2012 China also made a US $\$ 14$ million donation in the form of 4,910 tonnes of rice and 9,723 tonnes of wheat to Zimbabwe as Emergency Food Aid with the distribution modalities left to the government. From the country's annual food needs, the donation constituted 40 per cent and 3 per cent respectively of annual rice and wheat requirements for the country (The Herald 2012a).

In 2011, the China Export-Import Bank extended to Zimbabwe a loan facility for US\$334.7 million for procuring tractors and supporting the mechanisation programme for Zimbabwe's agricultural sector. Despite the loan agreement being subsequently ratified by the Parliament of Zimbabwe, it is yet to be drawn down. Some of the sticking points include a stipulation for 10 per cent down payment to activate the facility and that the debt has to be fully amortised in five years using agricultural produce.

At a lower, but no less significant level, the consignment of agricultural machinery was offered by the Sichuan Provincial Government of China, and comprised of 10 farm trucks, 30 walking (two wheel) tractors and 50 water pumps.

Lastly, after the suspension of government-togovernment cooperation programmes with traditional donor countries, China stepped in to partly fill the void with study tours and short courses for key personnel in Zimbabwe's Ministry of Agriculture. Parallel to that programme has been the secondment of agricultural experts from China to AGRITEX (the ministry's extension agency). Zimbabwe has been specifying the preferred skills in staff that are seconded. Ten experts have been coming on a one-year placement, with the first group completing their 'tour of duty' in 2011; in 2013, ten more are expected. The experts were seconded to AGRITEX Head Office and among their responsibilities has been the capacity building of the host institution in areas of land use planning, horticulture and agri-business. The experts developed training programmes and accompanied AGRITEX staff on field visits and extension outings. The Chinese government provides a stipend and is responsible for the general welfare of the experts.

In addition, a number of Chinese companies have established themselves in Zimbabwe to pursue business partnerships with local farmers. As explored in the next section, contract farming arrangements have been set up between Chinese companies and Zimbabwean tobacco and cotton farmers.

\section{Chinese contract farming in Zimbabwe}

Contract farming arrangements have been part of Zimbabwe's agricultural landscape in both the crop and livestock sectors since the mid-1950s (Woodend 2003), including in tobacco and cotton (especially since the expansion of smallholder production in the 1990s). In recent years, contract farming arrangements have become an 
even more significant form of funding agriculture in Zimbabwe as traditional sources of funds have become less able to do so of late. With the adoption of multiple currencies in 2009, a liquidity crunch has persisted with the result that the local banking sector has been even more constrained in its ability to provide funding. Irwin et al. (2012) estimate the total funding requirements for six major commodities (maize, paprika, cotton, tobacco, sugar cane, and coffee) at US $\$ 213$ million and projected a US\$136.58 million financing shortfall in the smallholder agricultural sector during the 2010/11 season. Tobacco and cotton under contract farming arrangements, however, have been better funded and are estimated to have got as much as 70 per cent of total 2011/12 season agricultural funding (Irwin et al. 2012).

Both tobacco and cotton are considered suitable for contracting arrangements as they are not consumed at household level and the marketing for each crop is through pre-determined channels. The Chinese companies comply with the same regulations as local companies: they need to provide each contracted farmer with adequate inputs for the contracted area; they need to provide proof of access to off-shore funds for purchasing the crop; and they are obliged to sell a specified quantity of the total crop to the local industry.

A Chinese company, Tian Ze Tobacco, has been one such contracting company and had an 11.7 per cent share of the total contract crop marketed in 2011 (TIMB 2012). ${ }^{2}$ In 2012, China maintained its position as the top buyer of Zimbabwe's tobacco (The Herald 2012b). Tian Ze Tobacco offered the highest average price among all foreign buyers which was also higher than the average price for last year's crop (US\$8.83 per kg from US $\$ 7.27$ in 2011). Most farmers contracted by Tian Ze are from the newly resettled areas as the company only contracts farmers who can commit at least 10 hectares to the crop in a season.

The company has been providing farmers with inputs and capital equipment needed, and recovering its money at the time of marketing. Each contracting company employs field officers who intensely monitor farmers on its schemes at all stages up until marketing. Of the companies that had contracts with tobacco farmers in 2011, Tian Ze offered the highest price - 13 per cent higher than the average among contracting companies (TIMB 2012).

Contract farming arrangements and the significant influx of buyers for the Chinese market have thus contributed significantly to the revival of the tobacco sector. Over the years, China has become Zimbabwe's largest buyer of tobacco with tobacco exports to that country more than doubling between 2010 and 2011, and constituting 21 per cent of Zimbabwe's 2011 export crop (TIMB 2012). An added benefit with exporting to China was the much higher price that the country offered in comparison to other destinations - a position that has raised the average national price for that crop and helped with Zimbabwe's economic recovery.

Seen within the broader context, a key initial consequence of land reform was the decline in tobacco deliveries. By 2006, deliveries had declined to a mere 23 per cent of the 2000 level of 236 million kg. ${ }^{3}$ Deliveries have since been recovering with tobacco accounting for 26 per cent of the country's total export earnings in 2011 (The Herald 2012b), and an expected output of 133.6 million $\mathrm{kg}$ in 2012 (AMID 2012b; Ministry of Finance 2012).

Contracting is also essential to the production of cotton. An estimated 300,000 smallholder farmers each commit an average area of 1 ha to produce cotton. This represents 99 per cent of total production (Esterhuizen 2009) and 95 per cent of it is grown under contract arrangements (Makoshori 2010). Under contract arrangements, farmers are provided with seed, fertiliser and chemicals, and are in turn obliged to hand over part of the harvested crop for the purpose of loan recovery.

Cotton is the only crop whose level of production was hardly affected by the FTLRP as it has traditionally been grown by smallholder farmers who have continued to be provided with inputs by merchants. Among the agricultural commodities exported, cotton brings in the second highest receipts after tobacco, with US\$150 million realised from lint exports over the period 1 May 2008-30 April 2009 (Esterhuizen 2009).

Sino Zimbabwe Cotton Holdings (SZCH) is among the smaller merchants that are registered to buy the crop. The company has been accused 
of undertaking predatory purchases and not grading the crop at buying, neither do they gin by grade. SZCH is said to be among the merchants who provided little or no production inputs but were very aggressive at the time of marketing through offering prices higher than other merchants and not restricting themselves to buying a crop they provided inputs for (MISA 2010). Unlike tobacco which is sold in Harare, cotton is sold at the farm-gate often in remote areas and it is alleged that SZCH buyers often operate under the cover of local politicians and that they buy any offered crop - even that grown under contract with other ginners. Such practices could hurt the industry in the long run and some merchants are already scaling back their input support programmes.

On the surface, South Africa is the single largest buyer of Zimbabwe's lint, accounting for 35-40 per cent whereas direct lint exports to China are only 8 per cent of the total. However, much more lint is exported to China from South Africa, with South African firms providing a 'warehousing' role. With cotton production in Zimbabwe continuing to grow, Chinese interests in the sector look likely to expand.

\section{Brazil's engagements with Zimbabwean agriculture}

The flagship of Brazil-Zimbabwe cooperation in agriculture is the More Food for Africa programme. Brazil launched it in 2008 with the aim of achieving food self-sufficiency at the small farm level, and spent over US $\$ 2.3$ billion on it between then and 2010. Initiatives to extend the programme to Africa began in 2010 at the BrazilAfrica Dialogue on Food Safety, Hunger Alleviation and Rural Development and have been spearheaded by the country's Ministry of Agrarian Development (MDA). Brazil's Chamber of Commerce (CAMEX) approved US $\$ 640$ million in lines of credit for the programme to Africa in the 2011-12 financial year. Under the programme, countries can obtain technical guidance from Brazilian specialists and may import equipment manufactured from that country. Ghana and Zimbabwe were the first African countries to join the programme.

In Zimbabwe, the programme was widely publicised with the signing of the $\mathrm{MoU}$ in August 2011. According to the MoU, Zimbabwe will receive agricultural machinery from Brazil through a loan agreement worth US\$98 million and the primary beneficiaries are to be smallholder farmers. The latest exchanges were in late September 2012 when Zimbabwe's Minister of Agriculture visited Brazil to confer with his counterpart to further consummate the programme. Currently, some logistical issues with Brazilian companies to supply the equipment are being finalised, as are technical specifications of the equipment and arrangements for collecting repayments in Zimbabwe. The main programme will focus on the importation of Brazilian tractors; however, an equally important component of the More Food for Africa package for Zimbabwe could be the supply of irrigation equipment, as it could make a major contribution in resuscitating and stabilising the agricultural sector and improving food security, particularly in smallholder farming areas.

Government officials in Brazil and Zimbabwe will administer the programme. In Brazil, the MDA will work with the companies supplying equipment and ensure that quality standards are maintained and prices are not increased unduly. In Zimbabwe, government officials are expected to train farmers in using the equipment and monitor its use, including maintenance.

Zimbabwe government officials will continuously assess agricultural production on beneficiary farms and assist with ensuring that farmers repay the loans.

The government of Zimbabwe will be the borrower and will repay the loan within ten years. Farmers are then expected to pay for the equipment within 15 years at 2 per cent interest. Considering the challenges with securing adequate funding that the government of Zimbabwe has been experiencing since the Zimbabwe dollar was demonetised - for example, registering a budget shortfall of US $\$ 98.6$ million between January and March 2012 (Ministry of Finance 2012) - the government could encounter problems servicing the loan, since the repayments by farmers are not synchronised with repayments to the government of Brazil.

A number of exchange visits by senior government officials have also been undertaken between the two countries in the lead-up to signing the MoU on the More Food for Africa programme and thereafter. From the 
government of Zimbabwe side, ministries involved include Agriculture, Mechanisation and Irrigation Development, and Finance and Investment Promotion. The government of Brazil has been represented by MDA, Embrapa and the Ministry of Foreign Affairs.

Furthermore, a private investment firm, Green Fuels, has set up a US\$600 million ethanol processing plant in Chisumbanje, South East Zimbabwe, as a joint venture with the Agricultural and Rural Development Authority, a quasi-state institution on whose estate the plant is located. The joint venture was to run for 20 years under a Build-Operate-Transfer arrangement. The Brazilian private sector provided the expertise in building the plant. Sugar cane is supplied primarily by the estate and is supplemented through out-grower arrangements with surrounding communal farmers. The ethanol is being sold as a 10 per cent blend with petrol at a price slightly lower than that of 100 per cent petrol. The product has received a lukewarm response from the market; without mandatory blending, the plant may have to shut down. The project has been mired in controversy with reports that a number of communal farmers were forcibly evicted with no compensation to make way for the expansion of the estate. Discussions are currently under way to run the project as a joint venture with government, with mandatory blending being enforced.

\section{Perceptions, relevance and possible impacts}

This section reflects on the distinguishing features of cooperation programmes by Brazil and China in the agricultural sector of Zimbabwe, as well as the perceptions, relevance and possible impacts emerging.

\subsection{The nature of the cooperation programmes}

Unlike programmes with traditional donors, engagement with China and Brazil is at government-to-government level, over the long to medium term. Traditional donors have been focusing on the poorest segments of the society and have not expected any repayments from the aid recipients. Moreover, they are only now restoring direct links with government after more than a decade. With the imposition of trade restrictions on main state entities and targeted sanctions on senior government and (then) ruling party officials ${ }^{4}$ by the European
Union, Western donors have worked with NGOs and others, as well as on relief and humanitarian aid programmes.

By contrast, the average size of Brazilian and Chinese aid per beneficiary is much larger, and not focused on the poorest and most vulnerable. For example, tractors are issued to individuals and input packs for tobacco are for a minimum of 10 hectares. Cooperation programmes with China and Brazil support fewer beneficiaries, and the ability to meet repayments is a major consideration. Beneficiaries have to make full payments on the inputs and capital equipment supplied and cash cropping has hitherto been the major component of such programmes. A major advantage with the China/Brazil cooperation programmes is that interest rates are much lower than those prevailing on the local market. The More Food for Africa programme will run for at least 15 years and the Chinese contract farming arrangements have no time limits. Protocols related to Chinese and Brazilian cooperation programmes are negotiated and signed at government level and the Zimbabwean government has provided the necessary guarantees. Implementation is overseen by government officials, unlike the case with traditional donors who are not obliged to share all information with government.

Cooperation programmes with Brazil and China in agriculture are anchored on commercial arrangements involving the private sectors of the two countries and are 'protected' as they are part of the aid protocols signed at government-togovernment level. With time, it is expected that the current strong links at government level between Zimbabwe and China/Brazil will be replaced by stronger contacts between private sector companies in Zimbabwe and their counterparts in Brazil and China, with the relationship continued on a commercial basis.

Cooperation with China, especially in tobacco, has already made an impact by reviving that sector. The higher prices that have been offered for the country's crop and the contract arrangements in place have spurred farmers to increase productivity. It is projected that if the current trend continues, the pre-FTLRP position could soon be surpassed. Enhanced tobacco receipts are resulting in an improvement in liquidity in the whole economy. 


\subsection{Changing perceptions towards China?}

Through engagements with China in wide areas of the economy, many more Zimbabweans now welcome Chinese investment. All political parties now share the view that the Chinese are sincere development partners, and the prime minister, whose party has been somewhat ambivalent of Chinese assistance is actively courting Chinese investment in other areas of the economy - for example, rehabilitating the country's roadnetwork, increased power generation, and the proposed giant pipeline of more than $400 \mathrm{~km}$ from the Zambezi river to supply water to the city of Bulawayo with irrigation water being provided to farms along the route.

Cotton farmers who benefited through 'predatory purchases' by SZCH were grateful for the higher producer prices offered although, in the long run, such a practice could be prejudicial to the prospects of the country's cotton industry and the reputation of its lint exports.

Zimbabwe's cotton has been ginned by grade and its lint has been sold at a premium on the world market due to its consistent quality. With reports that SZCH has not been ginning the crop by grade, there are fears that increased exports of Zimbabwe's lint by that company could result in a loss of the crop's premium status that had been painstakingly acquired.

Finally, the inclusion of the ATDC as part of the aid programme with China could be invaluable in that it could change the widely held perception that Chinese technology is inferior to that of the West, with Chinese-made goods earning the infamous tag Zhing-Zhong ${ }^{5}$ in Zimbabwe. The Chinese will run the ATDC for three years and thereafter hand it over to the government of Zimbabwe.

\subsection{Negotiated policy frameworks}

While the government of Zimbabwe has welcomed new development cooperation programmes and investment plans, these are guided by national policies. For example, all foreign investments in the agricultural sector have to conform to the Agricultural Policy (2012), Indigenisation and Economic Empowerment Act (2010) and the Industrialisation Development Policy (2011). However, how such policies are interpreted and implemented is open to some discretion, given the economic challenges faced by the Zimbabwean government.
The Agricultural Policy acknowledges the decline in the provision of credit to farmers and agribusiness in recent years due to general liquidity constraints in the economy, lack of collateral security, high cost of lending to some farm classes, insecurity of tenure and inaccessible lowcost international lines of credit (AMID 2012a). Contract farming arrangements through Tian Ze and SZCH are in line with this thrust, and any form of financing, including loan arrangements which may result in increased indebtedness (see Section 6.4) are welcome, given current financing constraints.

The Indigenisation and Economic Empowerment Act which became law in 2010 stipulates that 'at least 51 per cent of the shares of every public company and any other business shall be owned by indigenous Zimbabweans ${ }^{36}$ (Government of Zimbabwe 2010: 5). Under the Act, investment licences are only to be issued to companies that comply. In the case of an exemption, a timeline for eventual compliance is set.

However, the Minister of Indigenisation and Economic Empowerment has ruled that Chinese companies are exempted from complying with the law and that they are allowed to retain 100 per cent ownership since they are bringing in funds for supporting contract farming arrangements and are sub-contracting may smallholder farmers. Tian Ze was specifically mentioned in that regard, with it reported to have supported 250 contract farmers in the 2011-12 season (Chibaya 2012).

The government of Zimbabwe has raised concerns that most of its goods are exported in a raw or semi-processed form rather than as finished products. This earns the country less from exports and keeps the general economic activity in the country subdued. The contribution by the manufacturing sector to the country's GDP declined from 20 per cent in 2000 to 10 per cent in 2008 (MIC 2012). Cotton lint and tobacco are among commodities that could be processed further before export. The setting up of the ethanol plant has been in line with the Industrialisation Policy. In the long term, it is envisaged that the project will establish even stronger cooperation with Brazil, with the ultimate aim of setting up a local assembly plant for vehicles that run on high ethanol (Mutambara 2012). 
All policies are thus open to negotiation, and the preferential conditions offered to Chinese

businesses are witness to how such policies can be reinterpreted. Opportunities for rent-seeking by officials, as well as selective bypassing of regulations by Chinese investors have been noted by many commentators.

\subsection{Growing indebtedness}

Concerns have been raised on the implications of the increased indebtedness of the country to external partners through such cooperation programmes. Zimbabwe's current debt level is unsustainable and fears are that however much the aid programmes with China and Brazil are welcome, and indeed are imperative, they could entrench the country deeper into debt. The debt to GDP ratio for Zimbabwe was 104 per cent in 2010 (World Bank 2012) and has since worsened. As at June 2011, the country's total debt stood at US $\$ 8,754$ million; two thirds of the external debt (US $\$ 6,081$ million) was in arrears and 75 per cent of it was of a medium to long-term nature (World Bank 2012). The country is currently auditing its debt and developing a debt-restructuring plan. Such initiatives need to be accompanied by a major debt write-off by Zimbabwe's major creditors. In 2012 for instance, the country is reported to have defaulted to the tune of US $\$ 200$ million to China (Mashiri 2012).

As Zimbabwe pursues cooperation programmes with China, Brazil and other nations, it needs to revive ties with traditional donors that include the European Union, the USA, Canada, Japan and Australia ${ }^{7}$ and engage creditors with a view to getting some of its debt pardoned.

\subsection{Agricultural mechanisation: how appropriate?}

The Ministry of Agriculture, Mechanisation and Irrigation Development is still developing the agricultural mechanisation strategy for Zimbabwe and it is expected that the mechanisation components of the cooperation programmes with Brazil and China will be central.

As work is still under way in finalising the structure and components of the More Food for Africa cooperation programme with Brazil, it may be premature to comment on the suitability of the programme and its probable impacts. There have been inordinate delays in getting the first shipment of equipment made and it is hoped that once administrative arrangements are finalised, the programme will be rolled out quickly.

Considering the average size of small farms in Zimbabwe and their potential, the Brazilian model of supporting 'family farms' through the More Food programme may not be easily transferable. Zimbabwean smallholder farms are much smaller, with an average area of 2 hectares cropped each year. Due to the small average areas per household and low value of what is produced in communal areas, land preparation has been carried out by draught animal power rather than by tractors. However, most beneficiaries of the More Food for Africa programme could be drawn from high potential resettlement areas, with greater potential and larger farm sizes.

Evidence from farm settlement schemes in the 1980 s showed the medium-sized tractor $(65 \mathrm{kw}$; 60-70hp) as most appropriate; the smaller and larger units were less ideal due to higher operational costs. Furthermore, each unit can cope with an area of 60 hectares per year (AGRITEX 1983). Rusike (1988), however, questioned the appropriateness of tractors and their management under smallholder farming settings in Zimbabwe. Equally the government, the FAO and some Western donors are promoting no-till 'conservation agriculture', and Brazilian-funded tractors certainly do not fit into that remit.

\section{Conclusion}

While the investments of China and Brazil in Zimbabwean agriculture have come at a critical time, following a period of economic contraction and investment and donor boycotts, there are questions raised by the focus, modalities and implications of these engagements.

Certainly contract farming arrangements in tobacco and cotton as well as a deliberate policy of strengthening ties with China have helped the stabilisation and recovery efforts, especially since 2009. By contrast to the traditional donor support to poor and vulnerable farming households under the aegis of humanitarian and relief programmes, Brazil and China have focused on investment for growth, focusing on better-off farmers, with the potential for expanding production. Many of these are in the new resettlement areas which have been off limits for Western donors, due to continued sanctions. 
Cooperation programmes in the agricultural sector with Brazil and China provide larger individual investments per farm, are implemented over a longer time period, include capital equipment and are not restricted to the poor and vulnerable smallholder farmers, but focused on commercial production and growth opportunities. As much as they have been initiated and driven at government-to-government level, they are anchored on commercial ties.

The agricultural cooperation programme with China that started as a bilateral programme has grown tremendously over the years and has become dominated by commercial arrangements between private companies and the quasi-state institutions of the two countries. While such cooperation programmes are credited for the revival of the country's tobacco sector, concerns, however, have been raised in the cotton sector, with SZCH accused of some underhand dealings through buying a contracted crop, and undermining quality controls.

\section{Notes}

1 Commissioned by Zimbabwe's Vice-President Joice Mujuru.

2 In 2011, Tian Ze secured just over 50 per cent of the crop exported from Zimbabwe to China with other merchants supplying the rest.

3 'Zimbabwe Earns $\$ 517 \mathrm{~m}$ from Tobacco', www.newzimbabwe.com/business-8672Zimbabwe\%20earns\%20\$517m\%20from\%20 tobacco/business.aspx (accessed 1 December 2012).

4 The sole ruling party from independence in 1980 to 2008 was the Zimbabwe African National Union - Patriotic Front (ZANU-PF). Its stranglehold was only broken in 2009 when a Government of National Unity was formed with the Movement for Democratic Change following disputed elections. The EU has since been relaxing the sanctions but has not completely lifted them.

5 A Zimbabwean slang word meaning cheap, Asian-mostly-Chinese, of inferior quality. The
Regarding Brazil, the roll-out of the agricultural mechanisation programme is eagerly awaited, bearing in mind the dearth of funding for the agricultural sector - particularly of a medium and long-term nature. For the More Food for Africa programme to realise its intended benefits, however, thought is needed on the capital equipment suitable for each sector, as well as its ownership and management and debt repayment mechanisms.

In a period of economic and political isolation, Zimbabwe by necessity has reshaped its relationships with the wider world. As Western countries have shunned Zimbabwe and imposed sanctions and restricted investment and financing, Zimbabwe has looked elsewhere. New relationships with China and Brazil are pivotal, and are redefining the nature of agricultural development in terms of actors, commercial arrangements and focus.

word made its appearance at the onset of Chinese penetration into the Zimbabwean economy at the turn of the twenty-first century. It stems from the way the Chinese language sounds to a Zimbabwean hearing it for the first time, and from the names of the Chinese manufacturers on the labels of many cheap, low-quality products. Zhing-Zhong now also means anything that is low quality, even a person unfit for their occupation or station in life.

6 Indigenous Zimbabweans are defined as any person who before 18 April 1980 (date of independence) was disadvantaged by unfair discrimination on the grounds of his or her race.

7 Zimbabwe's MPs critical of Mugabe's 'Look East' Policy argued that there is no basis to neglect traditional markets in the West as the country is still developing links with the Far East markets (Chengu 2011). 


\section{References}

AGRITEX (1983) 'Guidelines for Labour and Equipment on Commercial Farms', unpublished training material for resettlement schemes, Harare, Zimbabwe: AGRITEX Farm Management Section AMID (2012a) Zimbabwe Agriculture Sector Policy Draft 1, May, Harare: Ministry of Agriculture, Mechanisation and Irrigation Development, Government of Zimbabwe

AMID (2012b) Second Round Crop and Livestock Assessment Report, 10 April, Harare: Ministry of Agriculture, Mechanisation and Irrigation Development, Government of Zimbabwe

Chengu, G. (2011) Zim-Brazil Relations:

Possibilities of a Look South Policy, Zimbabwe Broadcasting Corporation (ZBC), www.zbc.co.zw/news-categories/opinion/10825zimbrazil-relations-possibilities-of-a-looksouth-policy.html (accessed 15 February 2013)

Chibaya, M. (2012) 'Chinese Firms Immune to Indigenisation', The Standard, 16 September

Esterhuizen, D. (2009) Zimbabwe Commodity Report - Cotton and Products Annual, USDA Foreign Agricultural Service, http://gain.fas.usda.gov/ Recent\%20GAIN\%20Publications/Commodity \%20Report\%20-\%20Cotton\%20and\%20 Products\%20Annual_Pretoria_Zimbabwe_ 5-26-2009.pdf (accessed 20 June 2012)

European Union (2012) A Transitional Strategy for Food Security, policy and strategy paper prepared by the European Union Delegation to the Republic of Zimbabwe, Harare

Government of Zimbabwe (2010) Indigenisation and Economic Empowerment Act (chapter 14: 33), Harare, Zimbabwe: Government of Zimbabwe The Herald (2012a) 'China Donates US\$14m Goods', 2 March, www.herald.co.zw/index.php?option= com_content\&view $=$ article\&id $=35415$ : chinadonates-us $14 \mathrm{~m}$-goods \&catid $=47$ :agriculture $\&$ Itemid=139\#.UXGYE0qwJX9 (accessed 19 April 2013)

The Herald (2012b) 'China Top Tobacco Buyers List', 3 December, www.herald.co.zw/index.php? view $=$ article \&catid $=38 \% 3$ Alocal-news\&id $=$ 58929\%3Achina-top-tobacco-buyers-list\&format $=$ pdf\&option $=$ com_content\&Itemid $=131$ (accessed 15 February 2013)

Irwin, B.; Haley, S.D.; Chishakwe, N.E.; Vitoria, B. and Kudonhi, S. (2012) Building Agricultural Markets: Constraints and Opportunities in Contract Farming for Smallholder Agricultural Economy in Zimbabwe, final report prepared for the Zimbabwe Multi-Donor Trust Fund,
Agribusiness Systems International, Harare, Zimbabwe

Machadu, C. (2012) 'Look East Policy Bears no Fruit for Zim', The Zimbabwean, www.thezimbabwean.co.uk/news/zimbabwe/ 57665/look-east-policy-bears-no.html (accessed 15 February 2013)

Makoshori, S. (2010) 'Cotton Price Deadlock Takes New Twist', The Financial Gazette, www.financialgazette.co.zw/companies-amarkets/4509-cotton-price-deadlock-takesnew-twist.html (accessed 26 June 2012)

Mashiri, C. (2012) Zimbabwe's Debt Problem A Ticking Time Bomb, SW Radio Africa, www.swradioafrica.com/2012/07/06/zimbabwe s-debt-problem-a-ticking-time-bomb/ (accessed 1 December 2012)

MIC (Ministry of Industry and Commerce) (2012) Industrial Development Policy (2012-2016), www.zimtrade.co.zw/pdf/Government $\% 20$ policies/IDP.pdf (accessed 15 February 2013)

Ministry of Finance (2012) State of the Economy Report, statement prepared by the Minister of Finance Hon. T. Biti, Harare, Zimbabwe, March

Ministry of Finance (2011) 2012 National Budget: Sustaining Efficient Inclusive Growth in Jobs, presented to the Parliament of Zimbabwe by the Minister of Finance Hon. T. Biti, Harare, Zimbabwe, 24 November

Ministry of Finance (2009) Mid Year Fiscal Statement and Revised Budget, statement presented to the Parliament of Zimbabwe by the Minister of Finance Hon. T. Biti, Harare, Zimbabwe, 16 July

MISA (2010) 'Cotton Growers Ignore Regulations', The Zimbabwean, www.thezimbabwean.co.uk/ business,industry/33849/Cotton-growersignore-regulations (accessed 19 June 2012)

Mutambara, A. (2012) Report on the Stalled Chisumbanje Ethanol Project, report prepared by an Inter-Ministerial Committee of the Government of Zimbabwe chaired by Deputy Prime Minister, adopted by the Cabinet, Harare, Zimbabwe, September

Pazvakavambwa, S. (2007) 'Land Redistribution in Zimbabwe', paper presented at a workshop on Land Redistribution in Africa: Towards a Common Vision, World Bank

Rusike, J. (1988) 'Prospects for Agricultural Mechanisation in Communal Farming Systems: A Case Study of Chiweshe Tractor Mechanisation Project', MPhil thesis, University of Zimbabwe, Harare 
Scoones, I.; Marongwe, N.; Mavedzenge, B.; Murimbarimba, F.; Mahenehene, J. and Sukume, C. (2010) Zimbabwe's Land Reform: Myths and Realities, Oxford: James Currey; Harare: Weaver Press and Johannesburg: Jacana

TIMB (2012) 2011 Annual Statistical Report, Harare, Zimbabwe: Tobacco Industry and Marketing Board

Woodend, J. (2003) Potential of Contract Farming as a Mechanism for the Commercialisation of Smallholder
Agriculture: The Zimbabwe Case Study, draft report commissioned by Care International in Zimbabwe, Harare, Zimbabwe

World Bank (2012) Meeting of Multilateral Development Banks on Debt Issues, Washington DC, July 8-9, 2009: Chairman's Summary, http://siteresources.worldbank.org/INTDEBT DEPT/Resources/468980-1208804666078/ 4918561-1246380092176/2009MDBChairmans Summary.pdf (accessed 15 February 2013) 